\title{
Relationship between ECG Findings and Serum Biomarkers in COVID-19 Patients
}

\author{
Gökhan Perincek ${ }^{1}$, Muammer Karakayalı ${ }^{2}$, Sema Avc1 ${ }^{3}$ \\ ${ }^{1}$ Department of Pulmonology, Kars Harakani State Hospital, Kars, Turkey \\ ${ }^{2}$ Department of Cardiology, Kars Harakani State Hospital, Kars, Turkey \\ ${ }^{3}$ Department of Emergency Medicine, Uşak University Medical Faculty, Uşak, Turkey
}

\section{ABSTRACT}

Background and aim: The aim of this study was to evaluate the relationship between ECG findings and blood parameters indicative of inflammation and myocardial injury in COVID-19 patients. Methods: The study included 159 females and 194 males. Demographics, ECG findings (axis, rhythm, branch block, ST- and T-wave changes, premature ventricular contractions, early repolarization, S1Q3T3, fragmented QRS [fQRS], rate, PR, QRS, QT interval, QTc, P-wave dispersion) and albumin, D-dimer, ferritin, pro-BNP, procalcitonin, protein, troponin $\mathrm{T}$, neutrophil-to-lymphocyte ratio (NLR), C-reactive protein/albumin ratio (CAR) were recorded. Results: In the study, $45 \%$ of the cases were female and 55\% were male. The mean age of the included patients was $45.7 \pm 24.4$ years. The most frequent comorbidities were chronic obstructive pulmonary disease (COPD) and hypertension (HT) in both groups. The incidence of fQRS on the 1st day was significantly higher in patients with negative COVID-19 test (23\% for positive RT-PCR versus 35.6\% for negative RT-PCR, p = 0.016). QTC values on the 3rd and 5 th day were significantly higher in patients with negative RT-PCR ( $\mathrm{p}$ $=0.045$ and $p=0.042$, respectively). Albumin and procalcitonin were significantly higher in patients with positive COVID-19 test results ( $\mathrm{p}=0.018$ and $\mathrm{p}<0.001$, respectively). Patients with fragmented QRS presented significantly lower serum albumin $(40.62 \pm 4.73 \mathrm{~g} / \mathrm{L}$ vs. 42.92 $\pm 3.72 \mathrm{~g} / \mathrm{L}, \mathrm{p}=0.01)$, and protein levels $(\mathrm{p}=0.02)$, as well as lower lymphocyte count, and significantly higher levels of C-reactive protein $(47.01 \pm 65.01 \mathrm{mg} / \mathrm{L}$ vs. $24.55 \pm 44.17 \mathrm{mg} / \mathrm{L}, \mathrm{p}$ $=0.001)$, D-dimer $(\mathrm{p}=0.009)$, neutrophil count, pro-BNP $(\mathrm{p}=0.004)$, troponin $\mathrm{T}(\mathrm{p}<0.001)$, NRL and CAR $(1.28 \pm 1.83$ versus $0.6 \pm 1.11, \mathrm{p}<0.001)$. Conclusion: Patients with COVID-19 infection presented significantly higher levels of C-reactive protein, D-dimer, neutrophil, pro-BNP, procalcitonin, troponin T, NLR, and CAR, and significantly lower levels of albumin, lymphocyte count, and serum proteins, indicating the level of inflammation and its relationship with myocardial injury. Further follow-up studies are required, on larger patient sets, for the development of risk prediction tools in COVID-19 patients.

Keywords: COVID-19, electrocardiogram, fragmented QRS, inflammatory biomarkers, myocardial injury

\section{ARTICLE HISTORY}

Received: January 30, 2021

Accepted: May 23, 2021

\section{CORRESPONDENCE}

\section{Sema Avcı}

Department of Emergency Medicine, Uşak University Medical Faculty, Uşak, Turkey

Tel: +90 5308431363

E-mail: dnzlsema@gmail.com 


\section{INTRODUCTION}

Coronavirus disease 2019 (COVID-19) is an infectious condition caused by the severe acute respiratory syndrome coronavirus 2 (SARS-CoV-2), which was first diagnosed in China. ${ }^{1,2}$ In spite of the applied epidemiological measures, the disease was established as a pandemic in March $2020 .{ }^{1}$ COVID-19 varies in severity from little to no symptoms to severe pneumonia, respiratory distress, and death. In addition, the presence of associated risk due to advanced age, hypertension (HT), diabetes mellitus (DM), and cardiovascular diseases has been associated with increased mortality rates. ${ }^{3}$ COVID-19 affects the cardiovascular system and may have an array of clinical presentations. Electrocardiography (ECG) is a fast, simple, and noninvasive test that measures the electrical activity of the heart, thus allowing early diagnosis of cardiac disease. Fragmented QRS complex has been associated with increased risk of ventricular arrhythmias in various cardiovascular diseases. ${ }^{4}$ The aim of this study was to evaluate the relationship between ECG findings and blood parameters indicative for inflammation and myocardial injury in COVID-19 patients.

\section{MATERIALS AND METHODS}

\section{STUDY DESIGN AND POPULATION}

We conducted a cross-sectional prospective study in the Kafkas University Medical Faculty between March and June 2020. The study protocol was approved by the local ethics committee. We prospectively included 292 subjects (159 females, 194 males) with suspicion of COVID-19 infection who presented in the emergency room with specific symptoms. All included patients were tested for SARS-CoV-2 infection by sampling a nasopharyngeal probe which was analyzed by real-time polymerase chain reaction (RT-PCR) testing. The study population was categorized into two groups, according to positive and negative RT-PCR results. Age, gender, COVID-19 RT-PCR test results, comorbidities, smoking status, symptoms and signs, ECG findings (axis, rhythm, branch block, ST- and $\mathrm{T}$-wave changes, premature ventricular contractions [PVCs], early repolarization, $\mathrm{S} 1 \mathrm{Q} 3 \mathrm{~T} 3, \mathrm{fQRS}$, rate, $\mathrm{PR}$ interval, QRS duration, QT interval, QTc, P-wave dispersion) and laboratory results (albumin, C-reactive protein [CRP], D-dimer, ferritin, lymphocyte, neutrophil, pro-BNP, procalcitonin, protein, troponin $\mathrm{T}$, neutrophil-to-lymphocyte ratio [NLR], CRP/albumin ratio [CAR]) were recorded and compared between groups. A 12-lead ECG was obtained from each patient, and all standard 12-lead ECGs (Econet
Cardio M Plus, Germany; filtered 0.5-150 Hz, 25 mm/s, 10 $\mathrm{mm} / \mathrm{mV}$ ) were evaluated by an experienced cardiologist.

\section{STATISTICAL ANALYSIS}

The statistical analysis was performed with the use of SPSS 23.0 statistical software (SPSS for Windows, Chicago, IL, USA). Normal distribution was determined by applying the Kolmogorov-Smirnov test. Categorical parameters were compared using the Chi-squared and Fischer's exact test. The Mann-Whitney U test was used for non-normally distributed data in comparison of quantitative variables according to the binary group, and the independent two-sample $t$ test was used for comparison of normally distributed data. The Friedman test was used for nonnormally distributed variables to examine the changes of within-group parameters over three or more evaluations. Cochran's $Q$ test and the Friedman test were used to examine the changes of categorical parameters within groups according to three or more evaluations. Analysis results were presented as mean \pm standard deviation and median (minimum-maximum) for quantitative data, and as frequency (percentage) for categorical data. In the analyses, $\mathrm{p}<0.05$ was accepted as statistically significant.

\section{RESULTS}

In the study, 159 (45\%) of the cases were female and 194 (55\%) were male. The mean age of the included patients was $45.7 \pm 24.4$ years. Patients with a positive RT-PCR test for COVID-19 were significantly younger compared to those who tested negative (37.59 vs. 50.94 years, p $<0.001)$. Figure 1 and Table 1 illustrate the comparison between patients with positive and negative RT-PCR test for COVID-19 in regards to comorbidities. The most frequent comorbidities were chronic obstructive pulmonary disease (COPD) and hypertension (HT) in both groups. However, the incidence of these disorders was significantly higher in the negative RT-PCR group for both COPD ( $\mathrm{p}=0.001)$ and HT ( $\mathrm{p}<0.001)$.

The incidence of fQRS on the 1st day was significantly higher in the patients with negative COVID-19 test (23\% for positive RT-PCR vs. $35.6 \%$ for negative RT-PCR, $\mathrm{p}=$ 0.016). In patients with negative RT-PCR test results, the QRS axis was normal on day 1 in $77.4 \%$, on day 3 in $80.7 \%$, and on day 5 in $83.5 \%$ of cases $(\mathrm{p}=0.034)$. ST- and Twave changes were present in $36.8 \%$ of negative patients on day 1 , in $42.2 \%$ of patients on day 3 , and in $37.4 \%$ of patients on day $5(\mathrm{p}=0.041)$ compared to positive RT-PCR for COVID-19. QT intervals measured on day 3 and day 5 

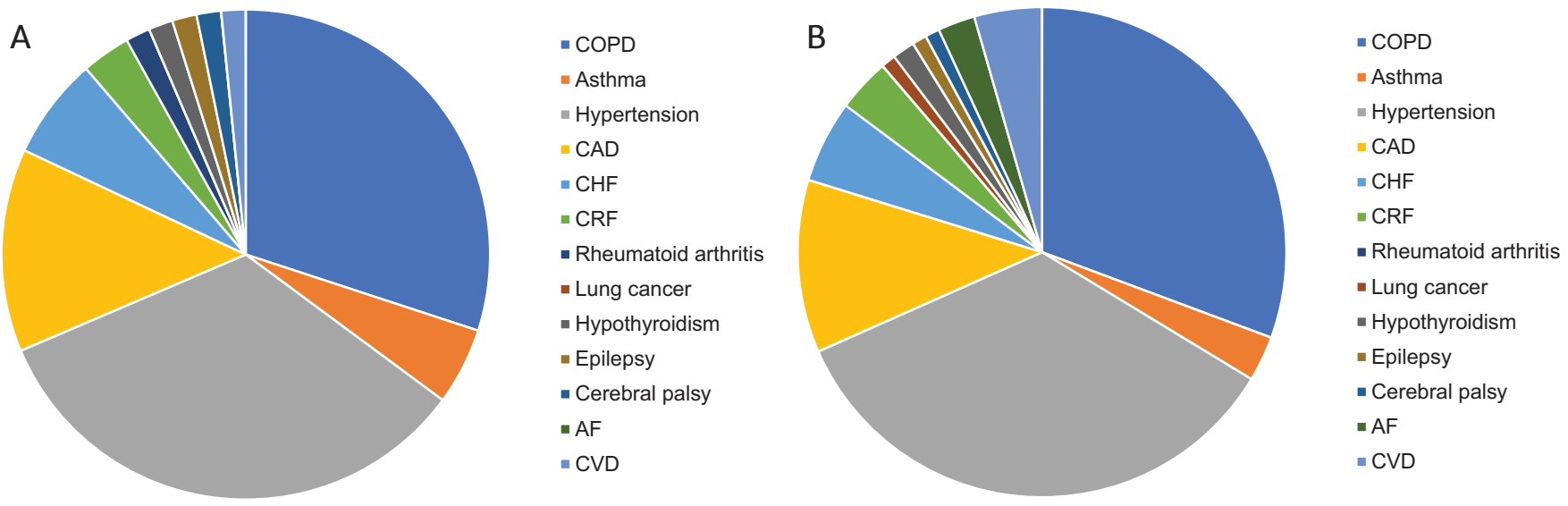

FIGURE 1. Comorbidities in patients with positive (A) and negative (B) RT-PCR test for COVID-19

were significantly higher in patients with negative RTPCR compared to those with positive RT-PCR ( $\mathrm{p}=0.037$ and $p=0.034$, respectively). QTc values on day 3 and day 5 were significantly higher in patients with negative RTPCR ( $\mathrm{p}=0.045$ and $\mathrm{p}=0.042$, respectively). The heart rate of negative RT-PCR patients on day 1 was significantly higher compared to patients with confirmed COVID-19 infection $(\mathrm{p}<0.001)$.

The comparative results for laboratory testing between positive and negative COVID-19 patients are listed in Table 2. Albumin and procalcitonin were significantly higher in patients with positive COVID-19 test results $(\mathrm{p}=0.018$; $\mathrm{p}<0.001$ respectively). CRP, D-dimer, neutrophil count, pro-BNP, troponin T, NLR, and CAR was significantly higher in those with negative COVID-19 test results, as shown in Table 2.

Table 3 presents a comparative analysis between patients with and without fQRS interval measured on day 1. Patients with fQRS presented significantly lower serum albumin $(40.62 \pm 4.73 \mathrm{~g} / \mathrm{L}$ vs. $42.92 \pm 3.72 \mathrm{~g} / \mathrm{L}, \mathrm{p}=0.01)$ and protein levels $(\mathrm{p}=0.02)$, as well as lower lymphocyte count, and significantly higher CRP levels $(47.01 \pm 65.01$

TABLE 1. Comparative analysis between RT-PCR positive and negative tests for COVID-19

\begin{tabular}{|c|c|c|c|}
\hline & $\begin{array}{l}\text { Positive RT-PCR } \\
\text { for COVID-19 }\end{array}$ & $\begin{array}{l}\text { Negative RT-PCR } \\
\text { for COVID-19 }\end{array}$ & $\begin{array}{c}\text { Total } \\
(n=292)\end{array}$ \\
\hline Fatigue, n (\%) & $28(20.3)$ & $42(19.5)$ & $70(19.8)$ \\
\hline Fever, n (\%) & $28(20.3)$ & $44(20.5)$ & $72(20.4)$ \\
\hline Arthralgia, n (\%) & $14(10.1)$ & $10(4.7)$ & $24(6.8)$ \\
\hline Headache, n (\%) & $22(15.9)$ & $32(15)$ & $54(15.3)$ \\
\hline Nausea/vomiting, n (\%) & $14(10.1)$ & $15(7)$ & $29(8.2)$ \\
\hline Diarrhea, n (\%) & $3(2.2)$ & $2(0.9)$ & $5(1.4)$ \\
\hline Dyspnea, n (\%) & $20(14.5)$ & $66(30.7)$ & $86(24.4)$ \\
\hline Cough, n (\%) & $39(28.3)$ & $82(38.1)$ & $121(34.3)$ \\
\hline Sore throat, n (\%) & $21(15.2)$ & $23(10.7)$ & $44(12.5)$ \\
\hline Chest pain, n (\%) & $5(3.6)$ & $24(11.2)$ & $29(8.2)$ \\
\hline Shivering, $\mathrm{n}(\%)$ & $6(4.3)$ & $7(3.3)$ & $13(3.7)$ \\
\hline Anosmia, n (\%) & $3(2.2)$ & $0(0)$ & $3(1.02)$ \\
\hline Ageusia, n (\%) & $4(2.9)$ & $0(0)$ & $4(1.3)$ \\
\hline Abdominal pain, n (\%) & $1(0.7)$ & $11(5.1)$ & $12(4.1)$ \\
\hline Dryness of the mouth, $\mathrm{n}(\%)$ & $1(0.7)$ & $0(0)$ & $1(0.34)$ \\
\hline Loss of appetite, n (\%) & $5(3.6)$ & $0(0)$ & $5(1.7)$ \\
\hline \multicolumn{4}{|l|}{ Smoking status } \\
\hline Never, n (\%) & $85(61.6)$ & $110(51.2)$ & $192(65.7)$ \\
\hline Current, n (\%) & $33(23.9)$ & $49(22.8)$ & $82(28)$ \\
\hline Ex-smoker, n (\%) & $20(14.5)$ & $56(26)$ & $76(26)$ \\
\hline
\end{tabular}


TABLE 2. Comparison of laboratory results between COVID-19 positive and negative patients

\begin{tabular}{|c|c|c|c|c|}
\hline $\begin{array}{l}\text { Laboratory parameter, mean } \\
\pm \text { SD (median, minimum- } \\
\text { maximum) }\end{array}$ & $\begin{array}{c}\text { Total } \\
(n=292)\end{array}$ & $\begin{array}{l}\text { Positive RT-PCR } \\
\text { for COVID-19 }\end{array}$ & $\begin{array}{l}\text { Negative RT-PCR } \\
\text { for COVID-19 }\end{array}$ & $p$ value \\
\hline Albumin & $\begin{array}{c}41.81 \pm 4.67 \\
42.6(24.1-51.3)\end{array}$ & $\begin{array}{c}42.69 \pm 4.08 \\
43.1(29.6-49.7)\end{array}$ & $\begin{array}{c}41.28 \pm 4.92 \\
42.1(24.1-51.3)\end{array}$ & 0.018 \\
\hline CRP & $\begin{array}{c}35.04 \pm 58.71 \\
10.32(0.3-342.74)\end{array}$ & $\begin{array}{c}13.05 \pm 29.36 \\
3.27(0.3-266.43)\end{array}$ & $\begin{array}{c}49.2 \pm 67.9 \\
20.03(0.97-342.74)\end{array}$ & $<0.001$ \\
\hline D-dimer (quantitative) & $\begin{array}{l}968.33 \pm 1,415.35 \\
485(150-10,151)\end{array}$ & $\begin{array}{l}796.61 \pm 1334.4 \\
347(150-9171)\end{array}$ & $\begin{array}{l}1,064.42 \pm 1,453.71 \\
590.5(150-10,151)\end{array}$ & 0.005 \\
\hline Ferritin & $\begin{array}{c}205.78 \pm 290.02 \\
125.15(3.79-2,000)\end{array}$ & $\begin{array}{c}198.26 \pm 297.36 \\
87.01(3.79-1,837)\end{array}$ & $\begin{array}{c}210.2 \pm 286.51 \\
138(6.66-2,000)\end{array}$ & 0.080 \\
\hline Lymphocyte count & $\begin{array}{c}1.98 \pm 1.37 \\
1.7(0.22-10.58)\end{array}$ & $\begin{array}{c}2.13 \pm 1.21 \\
1.8(0.36-7.24)\end{array}$ & $\begin{array}{c}1.89 \pm 1.46 \\
1.62(0.22-10.58)\end{array}$ & 0.116 \\
\hline Neutrophil count & $\begin{array}{c}6.62 \pm 5.16 \\
5.15(0.12-40.23)\end{array}$ & $\begin{array}{c}3.95 \pm 2.27 \\
3.34(0.84-13.56)\end{array}$ & $\begin{array}{c}8.34 \pm 5.74 \\
7.4(0.12-40.23)\end{array}$ & $<0.001$ \\
\hline Pro-BNP & $\begin{array}{l}999.18 \pm 4,057.91 \\
45.04(5-35,000)\end{array}$ & $\begin{array}{c}803.21 \pm 3,464.92 \\
31.7(5-24,483)\end{array}$ & $\begin{array}{c}1,137.66 \pm 4,447.12 \\
80.34(5-35,000)\end{array}$ & 0.015 \\
\hline Procalcitonin & $\begin{array}{c}0.98 \pm 8.6 \\
0.06(0.02-100)\end{array}$ & $\begin{array}{c}1.08 \pm 9.92 \\
0.05(0.02-99.32)\end{array}$ & $\begin{array}{c}0.93 \pm 7.74 \\
0.07(0.02-100)\end{array}$ & $<0.001$ \\
\hline Protein & $\begin{array}{c}70.79 \pm 7.35 \\
71.6(0-88.2)\end{array}$ & $\begin{array}{c}70.69 \pm 8.36 \\
71.75(0-82.7)\end{array}$ & $\begin{array}{c}70.85 \pm 6.7 \\
71.5(51.5-88.2)\end{array}$ & 0.854 \\
\hline Troponin $\mathrm{T}$ & $\begin{array}{c}12.4 \pm 24.25 \\
3.98(3-298.5)\end{array}$ & $\begin{array}{l}7.34 \pm 10.05 \\
3(3-55.78)\end{array}$ & $\begin{array}{c}15.16 \pm 28.89 \\
6.03(3-298.5)\end{array}$ & $<0.001$ \\
\hline NLR & $\begin{array}{c}5.19 \pm 6.04 \\
2.91(0.13-40.4)\end{array}$ & $\begin{array}{c}2.56 \pm 2.46 \\
1.75(0.16-19.72)\end{array}$ & $\begin{array}{c}6.88 \pm 6.98 \\
4.63(0.13-40.4)\end{array}$ & $<0.001$ \\
\hline $\begin{array}{l}\text { CAR (ratio between CRP and } \\
\text { albumin) }\end{array}$ & $\begin{array}{c}0.95 \pm 1.71 \\
0.26(0.01-10.09)\end{array}$ & $\begin{array}{c}0.33 \pm 0.76 \\
0.08(0.01-6.78)\end{array}$ & $\begin{array}{c}1.34 \pm 2 \\
0.47(0.02-10.09)\end{array}$ & $<0.001$ \\
\hline
\end{tabular}

$\mathrm{mg} / \mathrm{L}$ versus $24.55 \pm 44.17 \mathrm{mg} / \mathrm{L}, \mathrm{p}=0.001), \mathrm{D}$-dimer $(\mathrm{p}=$ 0.009), neutrophil count, pro-BNP ( $\mathrm{p}=0.004)$, troponin $\mathrm{T}$ $(\mathrm{p}<0.001), \mathrm{NRL}$, and CAR $(1.28 \pm 1.83$ vs. $0.6 \pm 1.11, \mathrm{p}<0.001)$.

\section{DISCUSSIONS}

In the study, fQRS, axis, ST- and T-wave changes, QT interval, QTc, heart rate, and P wave dispersion differed significantly according to the RT-PCR test results. While $23 \%$ of positive cases had an fQRS on the first day, $35.6 \%$ of negative cases also presented this ECG change that has been associated with an increased risk of severe ventricular arrhythmias. In the majority of cases, the QRS axis of patients with negative RT-PCR test for COVID-19 was normal on the first, third, and fifth day of evaluation. On the other hand, the corrected QT interval was lower in the majority of patients with confirmed SARS-CoV-2 infection on day 1,3 , and 5 .

fQRS complex, which associates increased risk of ventricular arrythmias, occurs in cardiac conditions such as coronary artery disease, cardiomyopathy, valvular heart disease, aortic dissection, pulmonary embolism, congenital heart disease, and channel pathologies, as well as non- cardiac diseases such as obstructive sleep apnea, renal disease, cirrhosis, radiotherapy, and autoimmune diseases. ${ }^{5}$ In a study conducted by Bektas et al., the prevalence of fQRS among patients with SARS-CoV-2 infection was $24 \% .{ }^{6}$ Barman et al. reported that the frequency of fQRS was significantly higher among patients with severe COVID-19 and those with myocardial damage. ${ }^{7}$ The reason for a higher frequency of ECG modifications may be due to the early ECG recording in negative patients, on their first admission. In our study, a significant proportion of COVID-19 negative patients did not present abnormal axis deviation. In a similar ECG study, Mccullough et al. reported $13.8 \%$ left axis deviation and $5.5 \%$ right or right superior axis deviation in COVID-19 patients. ${ }^{8}$ Angeli et al. reported that ST-T abnormalities, QTc duration, and heart rate were significantly decreased in patients with COVID-19 pneumonia during hospitalization, in a comparative analysis of ECG tracings from admission and at discharge. ${ }^{9}$ In the study of Barman et al., heart rate was associated with disease severity, but this was not affected by the presence of cardiac injury. ${ }^{7}$ In the same study, the QTC interval was not associated with disease severity or the presence of cardiac damage. ${ }^{7}$ Yenercag et al. reported 
TABLE 3. Comparison of laboratory results between patients with and without fragmented QRS interval measured on day 1

\begin{tabular}{|c|c|c|c|c|}
\hline $\begin{array}{l}\text { Laboratory parameter, mean } \\
\pm \mathrm{SD} \text { (median, minimum- } \\
\text { maximum) }\end{array}$ & $\begin{array}{c}\text { Total } \\
(n=292)\end{array}$ & With fQRS (+) & Without fQRS (-) & $p$ value \\
\hline Albumin & $\begin{array}{c}42.19 \pm 4.2 \\
42.8(27.5-51.3)\end{array}$ & $\begin{array}{c}40.62 \pm 4.73 \\
41.8(27.5-50.6)\end{array}$ & $\begin{array}{c}42.92 \pm 3.72 \\
43.3(29.6-51.3)\end{array}$ & 0.001 \\
\hline CRP & $\begin{array}{c}31.87 \pm 52.8 \\
10.1(0.3-286.38)\end{array}$ & $\begin{array}{c}47.01 \pm 65.01 \\
15.75(0.3-283.95)\end{array}$ & $\begin{array}{c}24.55 \pm 44.17 \\
6.26(0.3-286.38)\end{array}$ & 0.001 \\
\hline D-dimer & $\begin{array}{l}912.21 \pm 1,348.55 \\
475(150-10,151)\end{array}$ & $\begin{array}{c}1,115.59 \pm 1478.3 \\
631.5(150-9,708)\end{array}$ & $\begin{array}{l}815.5 \pm 1,276.36 \\
393(150-1,0151)\end{array}$ & 0.009 \\
\hline Ferritin & $\begin{array}{c}194.57 \pm 264.91 \\
128.4(3.79-2,000)\end{array}$ & $\begin{array}{c}217.38 \pm 258.51 \\
140.8(6.66-1,374)\end{array}$ & $\begin{array}{c}182.56 \pm 268.42 \\
125(3.79-2,000)\end{array}$ & 0.191 \\
\hline Lymphocyte count & $\begin{array}{c}1.77 \pm 0.87 \\
1.63(0.22-5.2)\end{array}$ & $\begin{array}{c}1.61 \pm 0.89 \\
1.51(0.22-5.2)\end{array}$ & $\begin{array}{c}1.84 \pm 0.85 \\
1.7(0.36-5.09)\end{array}$ & 0.031 \\
\hline Neutrophil count & $\begin{array}{c}6.45 \pm 4.05 \\
5.23(0.84-24.32)\end{array}$ & $\begin{array}{c}7.54 \pm 4.7 \\
6.26(1.25-24.32)\end{array}$ & $\begin{array}{c}5.94 \pm 3.61 \\
4.66(0.84-16.13)\end{array}$ & 0.011 \\
\hline Pro-BNP & $\begin{array}{l}473.27 \pm 1,739.9 \\
43.1(5-16,046)\end{array}$ & $\begin{array}{l}492.14 \pm 799.13 \\
134.9(5-3,763)\end{array}$ & $\begin{array}{c}465.56 \pm 2,006.42 \\
36.85(5-16,046)\end{array}$ & 0.004 \\
\hline Procalcitonin & $\begin{array}{c}0.18 \pm 0.39 \\
0.06(0.02-3.48)\end{array}$ & $\begin{array}{c}0.33 \pm 0.59 \\
0.1(0.02-3.48)\end{array}$ & $\begin{array}{c}0.1 \pm 0.190 .05 \\
(0.02-1.82)\end{array}$ & $<0.001$ \\
\hline Protein & $\begin{array}{c}71.87 \pm 5.89 \\
72.05(52.8-85.5)\end{array}$ & $\begin{array}{c}70.23 \pm 6.99 \\
70.9(52.8-83)\end{array}$ & $\begin{array}{c}72.64 \pm 5.15 \\
72.75(59.6-85.5)\end{array}$ & 0.024 \\
\hline Troponin $\mathrm{T}$ & $\begin{array}{c}10.2 \pm 14.07 \\
3.57(3-90.41)\end{array}$ & $\begin{array}{c}13.71 \pm 16.03 \\
7.68(3-90.41)\end{array}$ & $\begin{array}{l}8.43 \pm 12.67 \\
3(3-87.83)\end{array}$ & $<0.001$ \\
\hline NLR & $\begin{array}{c}5.03 \pm 5.22 \\
3.16(0.3-33.22)\end{array}$ & $\begin{array}{c}6.82 \pm 6.93 \\
4.42(0.37-33.22)\end{array}$ & $\begin{array}{c}4.2 \pm 3.94 \\
2.82(0.3-24.35)\end{array}$ & 0.002 \\
\hline $\begin{array}{l}\text { CAR (ratio between CRP and } \\
\text { albumin) }\end{array}$ & $\begin{array}{c}0.82 \pm 1.41 \\
0.23(0.01-8.68)\end{array}$ & $\begin{array}{c}1.28 \pm 1.83 \\
0.41(0.02-8.68)\end{array}$ & $\begin{array}{c}0.6 \pm 1.11 \\
0.15(0.01-7.07)\end{array}$ & $<0.001$ \\
\hline
\end{tabular}

that patients with COVID-19 had higher P-wave dispersion and P-wave duration compared to healthy subjects. ${ }^{10}$

In our study, albumin, lymphocyte and protein levels were significantly lower in patients with fQRS. Serum levels of CRP, D-dimer, neutrophils, pro-BNP, procalcitonin, troponin T, NLR, and CAR were significantly higher in patients who presented fQRS. In a study by Bektas et al., neutrophil, D-dimer, and CRP levels were higher in the fQRS-positive group, while lymphocyte and troponin levels were lower, but only CRP elevation was significantly increased. ${ }^{6}$ Ozcan et al. found that CRP levels were higher and troponin and albumin levels were lower in patients with fragmented QRS complexes, but the difference did not reach statistical significance. ${ }^{11}$ Inflammation plays a major role in all phases of heart disease, and CRP, CAR, NLR, and procalcitonin are inflammatory markers currently used to predict the prognosis of several diseases including coronary artery disease. ${ }^{12-16}$ Cardiac troponins, D-dimer, and pro-BNP are parameters commonly used to show coronary ischemia or cardiac injury. ${ }^{17-19}$ Coronary ischemia and inflammation caused by COVID-19 may lead to an increase in serum levels of these parameters for pa- tients with fQRS. In a study conducted by Kocaman et al., troponin levels were significantly higher in patients with fQRS. ${ }^{20}$ Radwan et al. found that cardiac troponins were higher in patients with $\mathrm{fQRS}$, and this group presented an increased risk for acute coronary syndromes. ${ }^{21}$ Zhao et al. reported that fQRS was significantly associated with proBNP, thus indicating a prognostic role for impaired ventricular systolic function. ${ }^{22}$

This single-center study had some limitations. Firstly, the size of the study population was relatively small, and the COVID-19 diagnosis was established using only RTPCR tests. Moreover, chest computed tomography findings of the patients were not included in the study.

\section{CONCLUSION}

Patients with COVID-19 infection presented significantly higher levels of CRP, D-dimer, neutrophils, pro-BNP, procalcitonin, troponin T, NLR, and CAR, and significantly lower levels of albumin, lymphocyte count, and serum proteins, thus indicating the level of inflammation and its relationship with myocardial injury. Moreover, patients 
with fragmented QRS complexes, that are at risk for developing major adverse cardiovascular events, presented significantly higher levels of inflammatory biomarkers (CRP, procalcitonin, neutrophil count, NLR), as well as increased biomarkers for myocardial injury and neurohormonal activation of the left ventricle (troponins, pro$\mathrm{BNP}$ ). The integration of several ECG parameters (fQRS, P-wave dispersion, QTc, heart rate) with serum biomarkers for inflammation and myocardial damage may provide prognostic information for patients with COVID-19 infection. Further follow-up studies are required, on larger patient sets, for the development of risk prediction tools in COVID-19 patients.

\section{CONFLICT OF INTEREST}

None declared.

\section{REFERENCES}

1. Anjorin AA. The coronavirus disease 2019 (COVID-19) pandemic: A review and an update on cases in Africa. Asian Pac J Trop Med. 2020;13:99-203. doi: 10.4103/1995-7645.281612.

2. Akçay Ş, Ozlu T, Yllmaz A. Radiological approaches to COVID-19 pneumonia. Turk J Med Sci. 2020;50:604-610. doi: 10.3906/sag-2004-160.

3. Abobaker A, Raba AA, Alzwi A. Extrapulmonary and atypical clinical presentations of COVID-19. J Med Virol. 2020;92:24582464. doi: 10.1002/jmv.26157.

4. Jin J. Screening for cardiovascular disease risk with ECG. JAMA. 2018;319:2346. doi: 10.1001/jama.2018.7311.

5. Supreeth RN, Francis J. Fragmented QRS-Its significance. Indian Pacing Electrophysiol J. 2020;20:27-32. doi: 10.1016/j. ipej.2019.12.005.

6. Bektaş $\mathrm{O}$, Çerik IB, Çerik HÖ, et al. The relationship between severe acute respiratory syndrome coronavirus 2 (SARSCOV- 2) pandemic and fragmented QRS. J Electrocardiol. 2020;62:10-13. doi: 10.1016/j.jelectrocard.2020.07.009.

7. Barman HA, Atici A, Alici G, et al. The effect of the severity COVID-19 infection on electrocardiography. Am J Emerg Med. 2021;46:317-322. doi: 10.1016/j.ajem.2020.10.005.

8. Mccullough SA, Goyal P, Krishnan U, Cho JJ, Safford MM, Okın PM. Electrocardiographic findings in coronavirus disease-19: insights on mortality and underlying myocardial processes. J Card Fail. 2020;26:626-632. doi: 10.1016/j. cardfail.2020.06.005.

9. Angeli F, Spanevello A, De Pontia R, et al. Electrocardiographic features of patients with COVID-19 pneumonia. Eur J Intern Med. 2020;78:101-106. doi: 10.1016/j.ejim.2020.06.015.
10. Yenerçağ M, Arslan U, Şeker O, et al. Evaluation of P-wave dispersion in patients with newly diagnosed coronavirus disease 2019. J Cardiovasc Med. 2021;22:197-203. doi: 10.2459/ JCM.0000000000001135.

11. Ozcan S, Cakmak HA, Ikitimur B, et al. The prognostic significance of narrow fragmented QRS on admission electrocardiogram in patients hospitalized for decompensated systolic heart failure. Clin Cardiol. 2013;36:560-564. doi: 10.1002/clc.22158.

12. Milano SS, de Moura Júnior OV, Souza Bordin AA, Marques GL. $\mathrm{C}$-reactive protein is a predictor of mortality in ST-segment elevation acute myocardial infarction. Int J Cardiovasc Sci. 2019;32:118-124. doi: 10.5935/2359-4802.20180086.

13. Shrivastava AK, Singh HV, Raizada A, Singh SK. C-reactive protein, inflammation and coronary heart disease. Egypt Heart J. 2015;67:89-97. doi: 10.1016/j.ehj.2014.11.005.

14. Efe SÇ, Candan ÖÖ, Gündoğan C, et al. Value of C-reactive protein/albumin ratio for predicting ischemia in myocardial perfusion scintigraphy. Mol Imaging Radionucl Ther. 2020;29:112-117. doi: 10.4274/mirt.galenos.2020.88261.

15. Santos HO, Moreira Izidoro LF. Neutrophil-Lymphocyte Ratio in Cardiovascular Disease Risk Assessment. Int J Cardiovasc Sci. 2018;31:532-537. doi: 10.5935/2359-4802.20180038.

16. Ataoğlu HE, Yılmaz F, Uzunhasan I, et al. Procalcitonin: a novel cardiac marker with prognostic value in acute coronary syndrome. J Int Med Res. 2010;38:52-61. doi: 10.1177/147323001003800106.

17. Ponikowski P, Voors AA, Anker SD, et al. 2016 ESC Guidelines for the diagnosis and treatment of acute and chronic heart failure. Eur Heart J. 2016;37:2129-2200. doi: 10.1093/eurheartj/ ehw128.

18. Yiğit Ö, Cete Y, Eken C, Göksu E. The sensitivity and specificity of high sensitive CRP, d-dimer and IL- 6 in acute coronary syndrome. Balkan Med J. 2011;28:429-434. doi: 10.5152/ balkanmedj.2011.010.

19. Panagopoulou V, Deftereos S, Kossyvakis C, et al. NTproBNP: an important biomarker in cardiac diseases. Curr Top Med Chem. 2013;13:82-94. doi: 10.2174/1568026611313020002.

20. Kocaman SA, Çetin M, Kırış T, et al. The importance of fragmented QRS complexes in prediction of myocardial infarction and reperfusion parameters in patients undergoing primary percutaneous coronary intervention. Turk Kardiyol Dern Ars. 2012;40:213-222. doi: 10.5543/tkda.2012.36937.

21. Radwan HI, Mansour KS, Al-Daydamony MM, Mohammed RS. Fragmented QRS complex as a predictor of high risk in acute coronary syndrome. Cardiol Cardiovasc Res. 2019;3:71-79. doi: 10.11648/j.ccr.20190303.16.

22. Zhao Q Zhang Q Hou J, Yu B. Relationship between fragmented QRS and NT-proBNP in patients with ST elevation myocardial infarction who underwent primary percutaneous coronary intervention. Acta Cardiol Sin. 2018;34:13-22. doi: 10.6515/ACS.201801_34(1).20170903A. 